\title{
PENGARUH MOTIVASI KERJA DAN KEMAMPUAN KERJA TERHADAP KINERJA UMKM DI KOTA PASURUAN (Studi pada UMKM Tahun 2018)
}

\author{
Eva Mufidah \\ Program Studi Manajemen, Fakultas Ekonomi, Universitas Merdeka Pasuruan \\ eva.mooev@gmail.com

\section{Raisa Fitri} \\ Progran Studi Kewirausahaan, Fakultas Ekonomi, Universitas Negeri Malang \\ raishav3@gmail.com
}

\begin{abstract}
Micro, Small and Medium Enterprises (MSMEs)have a significant role in national economic development. Empowerment of Micro, small and Medium Enterprises (MSMEs) is a strategic step in improving and strengthening the basic of economic life of the majority of the indonesian people, especially through providing employment and reducing in equality and poverty levels. The purpose of this study was to determine the effect of work motivation and work ability on the performance of MSMEs in Pasuruan city. The sampling technique used was purposive method sampling, taken as many as 85 units of MSMES. The data analysis technique used in this study wasmultiple linear regression analysis. The resultof regression coefficient of X1 variable of 0.987 shows that every increase in work motivation of one unit will cause an increase in the performance of MSMEs by 1 . The regression coefficient of variable X2 of 0.212 indicates that every increase in work capacity of one unit will cause a performance increase of 0.212 . The $R$ square in this study has a model suitability of $80.8 \%$, which means that work motivation and work ability are suitable variables to improve MSMEs performance by $11.2 \%$, the performance of MSMEs is influencedby other variables.
\end{abstract}

Keywords: Work Motivation, Employment Ability, Performance, Msmes

\section{PENDAHULUAN}

UMKM saat ini memiliki peran yang sangat besar tehadap pertumbuhan pembangunan ekonomi di Indonesia. Meskipun demikian potensi yang dimiliki UMKM tidak diimbangi dengan kemampuan mereka untuk bersaing. Tambunan (2008) mengungkapkan bahwa daya saing yang rendah dari UMKM dapat menyebabkan kelompok ini mengalami kesuliatan dalam peningkatan outputnya. Beberapa peneliti menjelaskan bahwa ketidakmampuan UMKM dalam meningkatkan daya saingnya karena UMKM memiliki keterbatasan, seperti, kurangnya untuk bisa beradaptasi dengan lingkungan, kurang cekatan dalam memanfaatkan peluang - peluang usaha, kurang kreativitas dan inovasi dalam menghadapi tantangan di luar lingkungan. Selain itu permasalahan yang ada dari dalam UMKM itu sendiri diantaranya, UMKM kurang memiliki kemampuan manajerial dan kurangnya permodalan serta jaringan pasar.

Pemberdayaan UMKM merupakan langkah strategis dalam meningkatkan dan memperkuat pertumbuhan perekonomian rakyat khususnya dengan menyediakan lapangan pekerjaan dan mengurangi kesenjangan, serta tingkat kemiskinan, sehingga upaya untuk perberdayaan UMKM harus terencana, sistematis dan menyeluruh.

Menurut Askolani dan Ressi J Machdalena (2011) menjelaskan bahwa hasil pengujian hipotesis motivasi dan kemampuan kerja berpengaruh terhadap kinerja. Pengaruh motivasi terhadap kinerja sebesar 54,9\% dan pengaruh kemampuan kerja terhadap kinerja sebesar 70,8\%. Sementara secara simultan motivasi dan kemampuan kerja menghasilkan pengaruh lebih besar tehadap kinerjasebesar $72,8 \%$ yang menunjukkan tingkat korelasi kuat, sehingga diperoleh kesimpulan bahwa motivasi 
dan kemampuan kerja mempengaruhi kinerja baik secara parsial maupun simultan akan tetapi pengaruh secara simultan lebih kuat dibandingkan secara parsial.

Kiki Rindi Arini, Muhammad Djudi Mukzam, Ika Ruhana (2015) menjelaskan bahwa motivasi kerja karyawan mendapatkan perhatian yang besar dari perusahaa, sehingga karyawan selalu diberi motivasi untuk meningkatkan semangat kerjanya. Hasil total mean variabel kemampuan kerja menunjukkan bahwa kinerja karyawan mendapat perhatian yang sangat besar bagi perusahaan, sehingga karyawan harus dapat meningkatkan kinerjanya agar perusahaan bisa berkembang dengan baik.

\section{KAJIAN TEORI}

UMKM merupakan usaha produktif perorangan maupun badan usaha yang memiliki usaha mikro. Hal ini sesuai dengan peraturan perundang - undangan No. 20 Tahun 200 sesuai pengertian UMKM, maka kriteria UMKM dibedakan secara masing -masing meliputi : usaha mikro, usaha kecil dan usaha menengah.

MenurutRudjito (2003), UMKM merupakan usaha yang mempunyai peran penting dalam pertumbuhan perekonomian Indonesia. Baik dari segi lapangan kerja maupun jumlah usaha, sedangkan menurut Kwartono (2008) UMKM merupakan kegiatan perekonomian rakyat yang mempunyai kekayaan bersih maksimal 200 juta, di mana tanah dan tempat bangunan tidak dihitung.

Motivasi Kerja menurut Malayu SP. Hasibuan (2006) motivasi berasaldari kata movereya itu dorongan. Motivasi menjelaskan bagaimana cara, daya dan potensi untuk mencapai tujuan yang ditentukan. Pada dasarnya seseorang bekerja untuk memenuhi kebutuhan hidupnya. Menurut Vroom dan Ngalim Purwanto (2006) motivasi adalah proses yang mempegaruhi suatu pilihan bagi individu tentang bentuk kegiatan yang dikehendaki yang mencakup sejumlah konsep seperti : dorongan (drive), kebutuhan (need), rangsangan (incentive), ganjaran (reward), penguatan (reinforcement), ketetapan tujuan (goal setting), harapan (expectancy), sehingga dari kesimpulan beberapa peneliti di atas bahwa motivasi merupakan dorongan untuk menciptakan gairah kerja, sehingga karyawan dapat bekerja sama secara efektif dan efisien.
Kemampuan Kerja menurutThoha (2011) kemampuan merupakan unsur dari kematangan yang berkaitan dengan pengetahuan dan keterampilan yang dapat diperoleh dari pendidikan, pelatihan dan pengalaman, sedangkan menurut Soelaiman (2007) kemampuan adalah sifat yang dibawa lahir yang memungkinkan seseoorang untuk menyelesaikan pekerjaannya, baik secara mental maupun fisik, sedangkan menurut Robbins (2006) Kemampuan kerja merupakan kapasitas individu untuk melaksanakan bermacam - macam tugas dalam pekerjaan tertentu, di mana kemampuan individu tersusun dari dua faktor, yaitu kemampuan intelektual dan kemampuan fisik. Kemampuan intelektual adalah kemampuan untuk menjalankan kegiatan mental diantaranya : berpikir, menganalisis dan memahami. Kemampuan intelektual diharapkan dapat meningkatkan kinerja organisasi, sedangkan kemampuan fisik adalah kemampuan untuk melaksanakan tugas yang menuntut stamina, kecekatan, kekuatan dan keterampilan. Berdasarkan uraian di atas bahwa karyawan dalam menjalankan tugas berdasarkan pengetahuan, sikap, pengalaman dan pendidikan.

Kinerja menurut Maharjan (2012) kinerja, yaitu suatu hasil yang dicapai karena termotivasi dan merasa puas dengan pekerjaan yang mereka lakukan. YulianadanSuhana (2012) dalam Astuti dan Dharmadiaksa (2014) kinerja merupakan keberhasilan yang dicapai seseorang dalam mengambil pekerjaan dibandingkan dengan standard kerja yang ditentukan sebelumnya. Menurut Viswesvaran dalam Jimoh (2008) menunjukkan bahwa kinerja karyawan merupakan perilaku, tindakan dan hasil yang diukur, di mana karyawan berkontribusi pada tujuan organisasi dan berhubungan dengan tujuan organisasi.

Menurut Gomez dalam Sastrowiharjo (2006) dalam melakukan penelitian terhadap kinerja berdasarkan deskripsi pekerjaan spesifik (judgement performance evaluation) ini disebutkan delapan dimensi yang perlu mendapat perhatian, antara lain:

1. Quality of work (kualitas kerja) akan dicapai berdasarkan syarat kesesuaian dan kesiapan.

2. Quantity of work (kuantitas kerja) merupakan jumlah kerja yang dilakukan dalam periode waktu tertentu.

3. Job knowledge (pengetahuan pekerjaan) merupakan pengetahuan pekerjaan dan keterampilan. 
4. Creativeness (kreatifitas) adalah gagasan yang ada dan tindakan untuk menyelesaikan masalah.

5. Cooperative (kerjasama) adalah adanya kesadaran bekerja sama dengan orang lain.

6. Initiative (inisiatif) merupakan ide-ide yang disampaikan sebagai program organisasi.

7. Dependerability (ketergantungan) adalah kesadaran yang dapatdipercayadalamhalkehadirandanpenjelas ankerja.

8. Personal quality (kualitas personal) menyangkut kepribadian dan kepemimpinan.

berikut:

Penulis merumuskan hipotesis sebagai

H1: Pengaruh motivasi kerja (motif, harapan dan insentif) terhadap kinerja UMKM di Kota Pasuruan

H2: Pengaruh kemampuan kerja (pengetahuan dan keterampilan) terhadap kinerja UMKM di Kota Pasuruan

H3: Pengaruh motivasi kerja dan kemampuan kerja terhadap kinerja UMKM di Kota Pasuruan.

\section{METODE PENELITIAN}

\section{Metode Pengumpulan Data}

Penelitian dilakukan dengan mengkaji sumber daya manusia pada UMKM. Pengkajian dilakukan untuk mengetahui dan menganalisis pengaruh motivasi kerja, kemampuan kerja dan kinerja UMKM. Penelitian dilaksanakan pada UMKM yanga ada di wilayah kota Pasuruan.

Populasi dari penelitian ini meliputi seluruh pelaku UMKM di wilayah kota Pasuruan yang masih aktif usahanya. Menurut data dari Dinas Koperasi dan UMKM, jumlah UMKM yang ada di kota Pasuruan sebanyak 829 unit. Teknik pengambilan sampel dengan menggunakan metode purposive sampling. Dari 829 UMKM diambil sebanyak 85 UMKM yag digunakan sebagai sampel dalam penelitian ini.

Penelitian ini menggunakan data primer dengan menyebar kuisioner yang diberikan kepada masing - masing pelaku UMKM. Sebelum peneliti melakukan survei, dilakukan penelitian pendahuluan. Penelitian pendahuluan dilakukan untuk menguji kevalidan dan keabsahan suatu kuisioner. Uji instrumen yang dilakukan adalah uji validitas dan uji reliabilitas.

\section{Teknik Analisis data}

Teknik analisis data yang digunakan dengan menggunakan analisis regresi linier berganda. Sebelum dilakukan analisis dilakukan pengujian hubungan antara masing - masing variabel tak bebas dengan variabel bebas dengan menggunakan koefisien korelasi Pearson. Uji asumsi yang melandasi analisis regresi linier berganda antara lain; asumsi normalitas, heterokedastisitas, non aotukorelasi, dan multikolinearitas. Uji signifikan dalam analisis regresi linear berganda, meliputi : uji simultan dengan menggunakan statisktik uji $\mathrm{F}$ dan uji parsial dengan menggunakan statistik uji t. Koefisien determinasi (R) digunakan untuk mengetahui seberapa besar variabel tak bebas dalam menjelaskan variabel bebas.

\section{HASIL DAN PEMBAHASAN}

\section{Hasil Analisis}

\section{Uji Validitas dan Reabilitas}

Validitas menjelaskan sejauh mana keakuratan tes dalam menjalankan fungsi pengukuran. Pengukuran dikatakan valid bila menghasilkan data yang akurat dan memberikan gambaran mengenai variable yang diukur. Berdasarkan hasil uji pada tabel 1 dapat diketahui nilai Cronbach's Alpha > 0,60 (Arikunto, 2010), artinya bahwa variabel Motivasi kerja memiliki tingkat kepercayaan yang tinggi

Tabel 1. Reability Reliability Statistics

\begin{tabular}{|c|c|c|}
\hline $\begin{array}{c}\text { Cronbach's } \\
\text { Alpha }\end{array}$ & $\begin{array}{c}\text { Cronbach's Alpha } \\
\text { Based on } \\
\text { Standardized } \\
\text { Items }\end{array}$ & $\begin{array}{c}\text { N of } \\
\text { Items }\end{array}$ \\
\hline, 959 &, 960 & 19 \\
\hline
\end{tabular}

Sumber: data diolah 2019-08-14

Dalam melihat valid atau tidak dapat dilihat dari Item-Total Correlation (r-hitung). Apabila rhitung lebih besar dari nilai batas, maka kuisioner tersebut dinyatakan valid. Dari tabel diatas dapat dilihat bahwa nilai Item-Total Correlation (r-hitung) setiap pertanyaan $>0,3$ 
sehingga kuisioner tersebut dinyatakan valid.

Tabel 2. Uji Validitas

Item-Total Statistics

\begin{tabular}{|c|c|c|c|c|c|}
\hline & $\begin{array}{c}\text { Scale } \\
\text { Mean } \\
\text { if } \\
\text { Item } \\
\text { Delet } \\
\text { ed }\end{array}$ & $\begin{array}{c}\text { Scale } \\
\text { Varian } \\
\text { ce if } \\
\text { Item } \\
\text { Deleted }\end{array}$ & \begin{tabular}{|l} 
Corre \\
cted \\
Item- \\
Total \\
Corre \\
lation
\end{tabular} & $\begin{array}{c}\text { Squ } \\
\text { ared } \\
\text { Mul } \\
\text { tiple } \\
\text { Corr } \\
\text { elati } \\
\text { on }\end{array}$ & $\begin{array}{l}\text { Cronba } \\
\text { ch's } \\
\text { Alpha } \\
\text { if Item } \\
\text { Delete } \\
\text { d }\end{array}$ \\
\hline $\mathrm{X} 1.1$ & 72,60 & 118,95 & ,444 & & ,962 \\
\hline $\mathrm{X} 1.2$ & 72,48 & 120,80 & ,450 & & ,961 \\
\hline $\mathrm{X} 1.3$ & 72,48 & $\begin{array}{r}117,94 \\
3\end{array}$ & 625 & & ,958 \\
\hline X1.4 & 72,48 & $\begin{array}{r}120,20 \\
5\end{array}$ & ,486 & & 960 \\
\hline X1.5 & 72,48 & $\begin{array}{r}114,49 \\
1\end{array}$ & 841 & & ,955 \\
\hline X1.6 & 72,48 & $\begin{array}{r}116,34 \\
8\end{array}$ &, 724 & & ,957 \\
\hline X1.7 & 72,48 & $\begin{array}{r}117,51 \\
5\end{array}$ & 651 & & 958 \\
\hline X1.8 & 72,49 & $\begin{array}{r}114,68 \\
2\end{array}$ & 838 & & ,956 \\
\hline X1.9 & 72,51 & $\begin{array}{r}116,27 \\
7\end{array}$ &, 744 & & 957 \\
\hline $\mathrm{X} 1.10$ & 72,48 & $\begin{array}{r}114,30 \\
0\end{array}$ & 853 & & ,955 \\
\hline $\mathrm{X} 1.11$ & 72,48 & $\begin{array}{r}115,51 \\
5\end{array}$ & ,776 & & ,956 \\
\hline $\mathrm{X} 1.12$ & 72,48 & $\begin{array}{r}114,30 \\
0\end{array}$ & 853 & & ,955 \\
\hline $\mathrm{X} 1.13$ & 72,48 & $\begin{array}{r}115,87 \\
2\end{array}$ & ,754 & & ,957 \\
\hline $\mathrm{X} 1.14$ & 72,48 & $\begin{array}{r}115,51 \\
5\end{array}$ & ,776 & & ,956 \\
\hline X1.15 & 72,48 & $\begin{array}{r}114,30 \\
0\end{array}$ & ,853 & & ,955 \\
\hline X1.16 & 72,48 & $\begin{array}{r}115,51 \\
5\end{array}$ & ,776 & & ,956 \\
\hline $\mathrm{X} 1.18$ & 72,48 & $\begin{array}{r}114,30 \\
0\end{array}$ & ,853 & & ,955 \\
\hline $\mathrm{X} 1.19$ & 72,48 & $\begin{array}{r}115,51 \\
5\end{array}$ & ,776 & & ,956 \\
\hline $\mathrm{X} 1.20$ & 72,48 & $\begin{array}{r}114,30 \\
0\end{array}$ & 853 & & ,955 \\
\hline
\end{tabular}

Sumber : data diolah, 2019

Berdasarkan keterangan diatas dapat ditarik kesimpulan bahwa variabel dan indikator mengenai motivasi usaha dinyatakan valid dan reliabel. Pada penelitian ini kemampuan kerja merupakan variabel X2. Untuk melihat reliabilitas dilakukan uji reliabilitas dengan menggunakan analisis Cronbach's Alpha. Pengambilan keputusan dilakukan dengan melihat nilai pada Cronbach's Alpha $>0,60$. Berikut ini adalah tabel uji validitas dan Uji reliabilitas variabel kemampuan kerja (X2). Tabel di bawah ini menunjukkan keandalan dari suatu variabel yang diteliti.

Tabel 3 Uji reliabilitas ReliabilityStatistics

\begin{tabular}{|c|c|}
\hline $\begin{array}{c}\text { Cronbach's } \\
\text { Alpha }\end{array}$ & $\begin{array}{c}\mathrm{N} \text { of } \\
\text { Items }\end{array}$ \\
\hline, 982 & 13 \\
\hline
\end{tabular}

Sumber : data diolah, 2019

Berdasarkan hasil penelitian tabel 1 tersebut (tabel reliabilitas) bahwa variabel penelitian memiliki tingkat kepercayaan berdasarkan nilai Cronbach's Alpha > 0,60, artinya bahwa variabel kemampuan kerja memiliki tingkat kepercayaan yang tinggi.

Tabel 4. Uji Validitas Kemampuan Kerja Item-Total Statistics

\begin{tabular}{|l|c|c|c|c|}
\hline & $\begin{array}{c}\text { Scale } \\
\text { Mean } \\
\text { if } \\
\text { Item } \\
\text { Delet } \\
\text { ed }\end{array}$ & $\begin{array}{c}\text { Scale } \\
\text { Varian } \\
\text { ce if } \\
\text { Item } \\
\text { Deleted }\end{array}$ & $\begin{array}{c}\text { Correct } \\
\text { ed } \\
\text { Item- } \\
\text { Total } \\
\text { Correla } \\
\text { tion }\end{array}$ & $\begin{array}{c}\text { Cronbach's } \\
\text { Alpha if } \\
\text { Item } \\
\text { Deleted }\end{array}$ \\
\hline X2.1 & 39,52 & 81,348 &, 560 &, 990 \\
X2.2 & 39,53 & 74,633 &, 994 &, 978 \\
X2.3 & 39,53 & 74,633 &, 994 &, 978 \\
X2.4 & 39,53 & 74,633 &, 994 &, 978 \\
X2.5 & 39,53 & 74,633 &, 994 &, 978 \\
X2.6 & 39,53 & 74,633 &, 994 &, 978 \\
X2.7 & 39,47 & 78,157 &, 844 &, 982 \\
X2.8 & 39,41 & 81,578 &, 695 &, 985 \\
X2.9 & 39,53 & 75,038 &, 967 &, 979 \\
X2.10 & 39,51 & 74,586 &, 981 &, 979 \\
X2.11 & 39,51 & 74,586 &, 981 &, 979 \\
\hline X2.12 & 39,51 & 74,586 &, 981 &, 979 \\
\hline X2.13 & 39,51 & 74,515 &, 947 &, 980 \\
\hline
\end{tabular}

Sumber: data diolah, 2019

Untuk melihat kuisioner tersebut valid atau tidak, dapat diliat dari Item-Total Correlation (r-hitung). Apabila r-hitung lebih besar dari nilai batas maka kuisioner tersebut 
dinyatakan valid.dari tabel diatas daapt dilihat bahwa nilai Item-Total Correlation (r-hitung) setiap pertanyaan $>0.3$, sehingga kuisioner tersebut dinyatakan valid.

Berdasarkan keterangan diatas dapat disimpulkan, bahwa kuesioner mengenai Kemampuan kerja inyatakan valid. Uji reabilitas juga dilakukan untuk menguji kinerja UMKM. Berdasarkan hasil penelitian nilai reliabilitas penelitian sebesar 0,965. nilai Cronbach's Alpha $>0,60$, artinya bahwa variabel kineja memiliki tingkat kepercayaan yang tinggi.

Tabel 5.Reliabilitas Kinerja UMKM Reliability Statistics

\begin{tabular}{|r|c|r|}
\hline & $\begin{array}{c}\text { Cronbach's } \\
\text { Alpha } \\
\text { Based on } \\
\text { Standardize } \\
\text { d Items }\end{array}$ & \\
Cronbach of Items \\
s Alpha
\end{tabular}

Sumber: data diolah, 2019

Tabel 6. ValiditasKinerja UMKM Item-Total Statistics

\begin{tabular}{|c|c|c|c|c|c|}
\hline & $\begin{array}{l}\text { Scale } \\
\text { Mean if } \\
\text { Item } \\
\text { Deleted }\end{array}$ & $\begin{array}{c}\text { Scale } \\
\text { Varian } \\
\text { ce if } \\
\text { Item } \\
\text { Deleted }\end{array}$ & \begin{tabular}{|l|} 
Corre \\
cted \\
Item- \\
Total \\
Corre \\
lation
\end{tabular} & $\begin{array}{c}\text { Squ } \\
\text { ared } \\
\text { Mul } \\
\text { tiple } \\
\text { Corr } \\
\text { elati } \\
\text { on }\end{array}$ & $\begin{array}{l}\text { Cronbac } \\
\text { h's } \\
\text { Alpha if } \\
\text { Item } \\
\text { Deleted }\end{array}$ \\
\hline $\mathrm{y}_{-} 1$ & 93,13 & 181,85 & 635 & & \\
\hline $\mathrm{y} \_2$ & 93,13 & $\begin{array}{r}175,28 \\
1\end{array}$ & ,965 & & 96 \\
\hline y_3 & 93,13 & $\begin{array}{r}175,28 \\
1\end{array}$ & 965 & & 961 \\
\hline y_4 & 93,13 & $\begin{array}{r}175,28 \\
1\end{array}$ & ,965 & & 961, \\
\hline y_5 & 93,13 & $\begin{array}{r}175,28 \\
1\end{array}$ & ,965 & & 961 \\
\hline y_6 & 93,13 & $\begin{array}{r}175,28 \\
1\end{array}$ & ,965 & & ,961 \\
\hline $\mathrm{y}_{-} 7$ & 93,12 & $\begin{array}{r}183,20 \\
0\end{array}$ & ,563 & & 965 \\
\hline $\mathrm{y} \_8$ & 93,11 & $\begin{array}{r}190,73 \\
9\end{array}$ & ,202 & & ,968 \\
\hline y_9 & 93,12 & $\begin{array}{r}180,81 \\
9\end{array}$ & 679 & & 964 \\
\hline
\end{tabular}

Sumber: data diolah, 2019

\begin{tabular}{|c|c|c|c|c|c|}
\hline \multicolumn{5}{|c|}{ Item-Total Statistics } & \multirow[b]{2}{*}{$\begin{array}{l}\text { Cronbach' } \\
\text { s Alpha if } \\
\text { Item } \\
\text { Deleted }\end{array}$} \\
\hline & $\begin{array}{c}\text { Scale } \\
\text { Mean } \\
\text { if Item } \\
\text { Delete } \\
\text { d }\end{array}$ & \begin{tabular}{|c} 
Scale \\
Varia \\
nce if \\
Item \\
Delet \\
ed
\end{tabular} & \begin{tabular}{|c|} 
Correct \\
ed \\
Item- \\
Total \\
Correla \\
tion
\end{tabular} & \begin{tabular}{|c|} 
Squar \\
ed \\
Multi \\
ple \\
Corre \\
lation \\
\end{tabular} & \\
\hline $\mathrm{y}_{-} 10$ & 93,12 & $\begin{array}{r}177,1 \\
53\end{array}$ & ,862 & & 962 \\
\hline $\mathrm{y} \_11$ & 93,08 & $\begin{array}{r}177,6 \\
72\end{array}$ & ,866 & & ,962 \\
\hline $\mathrm{y} \_12$ & 93,08 & $\begin{array}{r}178,5 \\
20\end{array}$ & ,882 & & ,962 \\
\hline y_13 & 93,13 & 179,0 & ,773 & & ,963 \\
\hline $\mathrm{y}_{-} 14$ & 93,13 & 181,8 & 635 & & ,964 \\
\hline y_15 & 93,12 & $\begin{array}{r}183,2 \\
0\end{array}$ & 563 & &, 965 \\
\hline $\mathrm{y}_{-} 16$ & 93,11 & $\begin{array}{r}190,7 \\
\end{array}$ & ,202 & & ,968 \\
\hline y_17 & 93,12 & $\begin{array}{r}180,8 \\
19\end{array}$ & 679 & & ,964 \\
\hline $\mathrm{y} \_18$ & 93,12 & 177,1 & ,862 & & 962 \\
\hline $\mathrm{y}_{-} 19$ & 93,11 & $\begin{array}{r}175,8 \\
58\end{array}$ & ,919 & & 962 \\
\hline $\mathrm{y} \_20$ & 93,12 & 183,2 & ,563 & & ,965 \\
\hline y_21 & 93,11 & $\begin{array}{r}190,7 \\
\end{array}$ & 202 & & ,968 \\
\hline y_22 & 93,12 & $\begin{array}{r}180,8 \\
19\end{array}$ & 679 & & ,964 \\
\hline & 93,12 & $\begin{array}{r}177,1 \\
53\end{array}$ & ,862 & & ,962 \\
\hline$y \_24$ & 93,11 & $\begin{array}{r}174,9 \\
29\end{array}$ & 911 & & 962 \\
\hline
\end{tabular}

Sumber: data diolah, 2019

Valid atau tidaknya dapat dilihat dari Item - Total Correlation (r-hitung). Apabila rhitung lebih besar dari nilai batas, maka kuisioner tersebut dinyatakan valid. Dari tabel 6 kinerja UMKM dapat dilihat bahwa nilai Item-Total Correlation (r-hitung) setiap petanyaan $>0,2$ sehingga kuisioner tersebut dinyatakan valid, sehingga kesimpulannya variabel penelitian yaitu kinerja UMKM valid dan reliabel.

\section{Uji Hipotesis}

Uji hipotesis dilakukan dengan uji t yang dikenal dengan uji parsial yaitu untuk menguji 
bagaimana pengaruh masing-masing variabel bebasnya secara sendiri-sendiri terhadap variabel terikatnya. Uji ini dapat dilakukan dengan membandingkan $t$ hitung dengan $t$ tabel atau dengan melihat kolom signifikansi pada masingmasing t hitung.

Tabel 7 .Ujihipotesis

Coefficients $^{\mathrm{a}}$

\begin{tabular}{|c|c|c|c|c|c|}
\hline \multirow[b]{2}{*}{ Model } & \multicolumn{2}{|c|}{$\begin{array}{c}\text { Unstandar } \\
\text { dized } \\
\text { Coefficien } \\
\text { ts }\end{array}$} & $\begin{array}{c}\text { Standard } \\
\text { ized } \\
\text { Coefficie } \\
\text { nts }\end{array}$ & & \\
\hline & B & $\begin{array}{c}\text { Std. } \\
\text { Erro } \\
\text { r }\end{array}$ & Beta & $\mathrm{t}$ & Sig. \\
\hline 1 (Constant) & 12,3 & & & 2,68 & ,009 \\
\hline $\mathrm{X} 1$ & ,98 &, 090 & , 146 & 2,36 & 020 \\
\hline $\mathrm{X} 2$ & & & & $\begin{array}{r}13,04 \\
8\end{array}$ & \\
\hline
\end{tabular}

a. Dependent Variable: Y

Sumber : data diolah, 2019

Berdasarkan uji regresi berganda persamaan dasar penelitian dirumuskan dengan $\mathrm{Y}=12,383+0,987 \mathrm{X} 1+0,212 \mathrm{X} 2+\mathrm{e}$. Bisa dijelaskan bahwa kenaikan motivasi kerja dan kemampuan kerja mampu meningkatkan kinerja UMKM, hal ini ditunjukkan oleh koefisien variabel $\mathrm{X} 1$ dan koefisien variabel $\mathrm{X} 2$ yang bernilai positif. Semakin tinggi motivasi kerja dan kemampuan kerja akan semakin meningkat kinerja UMKM. Untuk menemukan adanya pengaruh masing masing variabel maka akan dilakukan uji hipotesis yang didasarkan pada Tabel 7 tersebut di atas. Hipotesis yang dirumuskan pada penelitian ini adalah:

H1: Motivasi kerja mempunyai pengaruh terhadap kinerja UMKM

Koefisien regresi untuk variabel independen bernilai positif menunjukkan adanya hubungan searah antara variable independendan variable dependen. Sehingga apabila motivasi kerja ditingkatkan maka dapat meningkatkankinerja UMKM. Koefisien regresi variabel X1 sebesar 0,987 menunjukkan bahwa setiap peningkatan motivasi kerja sebesar satu satuan akan menyebabkan peningkatan kinerja UMKM sebesar 1. Dari tabel diatas nilai t hitung sebesar 2,369 dan t tabel 1,663 dengan nilai sig.sebesar $0,002(>0,05)$, maka hipotesis pertama tidak diterima. Sehingga dapat ditarik kesimpulan bahwa motivasi kerja tidak berpengaruh terhadap kinerja UMKM

$\mathrm{H} 2$ : Kemampuan kerja mempunyai pengaruh terhadap kinerja UMKM

Koefisien regresi variabel independen bernilai positif menunjukkan adanya hubungan searah antara variabel independen dengan variabel dependen. Sehingga bila kemampuan kerja ditingkatkan maka dapat meningkatkan kinerja UMKM. Koefisien regresi variabel X2 sebesar 0,212 menunjukkan bahwa setiap peningkatan kerja sebesar satu satuan, maka akan menyebabkan peningkatan kinerja sebesar 0,212. Dari tabel diatas, nilai t hitung sebesar 13,048 dan t tabel 1,663 nilai sig.sebesar $0,00(>0,05)$ maka hipotesis kedua diterima. Dapat ditarik kesimpulan bahwa kemampuan kerja berpengaruh terhadap kinerja UMKM. Tabel berikut menunjukkan hasil uji simultan variabel motivasi kerja dan kemampuan kerja terhadap kinerja UMKM. Hipotesis dapat dirumuskan sebagai berikut:

Tabel 8. Uji Simultan ANOVA $^{a}$

\begin{tabular}{|l|r|r|r|r|r|}
\hline Model & $\begin{array}{c}\text { Sum of } \\
\text { Squares }\end{array}$ & df & $\begin{array}{r}\text { Mean } \\
\text { Square }\end{array}$ & F & Sig. \\
\hline $\begin{array}{l}\text { Regres } \\
\text { sion }\end{array}$ & 13292,402 & 2 & 6646,2 & 172, & 01 \\
$\begin{array}{l}\text { Residu } \\
\text { al }\end{array}$ & 3153,292 & 82 & 38,455 & & \\
Total & 16445,694 & 84 & & & \\
\hline
\end{tabular}

a. Dependent Variable: Y

b. Predictors: (Constant), X2, X1

Sumber: data diolah, 2019

H3 : Motivasi kerja dan kemampuan kerja mempunyai pengaruh terhadap kinerja UMKM.

Tabel 9. R Square

Model Summary

\begin{tabular}{|l|c|r|r|r|}
\hline Model & $\mathrm{R}$ & $\begin{array}{c}\mathrm{R} \\
\text { Square }\end{array}$ & $\begin{array}{r}\text { Adjusted } \\
\text { R Square }\end{array}$ & $\begin{array}{r}\text { Std. Error of } \\
\text { the Estimate }\end{array}$ \\
\hline 1 &, $899^{2}$ &, 808 &, 804 & 6,201 \\
\hline
\end{tabular}


a. Predictors: (Constant), X2, X1

Sumber : data diolah, 2019

Berdasarkan tabel di atas, maka dapat Hasil penelitian juga menunjukkan diintepretasikan sebagai berikut. Sig.F yaitu sebesabahwa kemampuan kerja pelaku UMKM mampu $0,00 \leq \alpha(0.05)$ dapat diartikan bahwa motivasi kerjmeningkatkan kinerja. Adanya pengetahuan dan dan kemampuan kerja secara bersama - samketrampilan dalam menjalankan usaha akan mempengaruhi kinerja UMKM.

Hasil uji statistic R Square bahwa penelitian ini memiliki kesesuaian model sebesar 80,8\% artinya Motivasi kerja dan Kemampuan kerja merupakan variabel yang cocok untuk meningkatkan kinerja UMKM. Sebesar 11,2\% kinerja UMKM di pengaruhi oleh variabel lain. Berdasarkan hasil pengetahuan dapat dijelaskan bahwa motivasi kerja para UMKM di kota Pasuruan mampu meningkatkan kinerja UMKM didaerah tersebut. Motivasi kerja yang dimaksud adalah lingkungan kerja yang nyaman, keberadaan UMKM yang diakui, adanya kesempatan untuk mengembangkan diri, dan adanya kesempatan para pemilik UMKM dalam membimbing atau mengarahkan karyawannya agar bisa menyelesaikan tugas dengan baik maka kondisi ini akan meningkatkan kinerja UMKM yang berupa penikangkatan kreativitas pelaku UMKM, ketepatan waktu dalam menyelesaikan tugas adan adanya sinergi serta kerjasama pelaku UMKM.

Seperti kita ketahui bahwa kinerja UMKM ini selalu meningkat yang ditunjukkan dengan adanya beberapa hal yang didukung oleh program pemerintah dan CSR beberapa perusahaan di kota Pasuruan. Adanya peran pemerintah dan perusahaan swasta ini akan memberikan kesempatan bagi UMKM untuk terus mengembangkan usahanya, dimana mereka memiliki kesempatan mengembangkan usaha dibidang produksi, permodalan dan keuangan.

Dukungan pemerintah untuk meningkatkan kinerja UMKM dengan memberikan program layanankewirausahaan yang mandiri, professional dan berdaya saing dalam beragam bentuk pendampingan yang meliputi : memberikan konsultasi bisnis, Menyediakan informasi bisnis, layanan pendampingan, Melaksanakan pelatihan gratis bagi masyarakat/ calon wirausaha baru, layanan akses pembiayaan, layanan akses pemasaran produk. Keberadaan UMKM yang didukung penuh oleh semua pihak, kesempatan untuk berkembang pelaku UMKM (Motivasi Kerja) akan meningkatkan kinerja UMKM dari berbagai hal baik dari segi keuangan maupuan meningkatkan kinerja UMKM. Para pelaku UMKM di kota Pasuruan rata-rata memiliki pengetahuan dalam menjalankan usaha baik pengetahuan di bidang produksi, permodalan atau akses keuangan maupun pemasaran. Kondisi ini tidak terlepas dari peran pemerintah maupun swasta dalam bentuk tanggungjawab perusahaan pada masyarakat yang melakukan pendampingan dan pembimbingan bagi pelaku UMKM.

Berbagai program pemerintah dan perusahaan dengan melakukan pendampingan bagi pelaku UMKM melalui pembentukan paguyuban UMKM, membantu pengurusan SIUP dan TDP, memfasilitasi pemasaran produk UMKM. Dengan program layanan kewirausahaan yang mandiri, professional, dan berdaya saing dalam bentuk ragam pendampingan, meliputi : pemberian konsultasi bisnis, penyediaan informasi bisnis, layanan pendampingan, layanan akses pembiayaan, ini akan meningkatkan kemampuan kerja para pelaku UMKM dalam bentuk pengetahuan dan keterampilan yang akhirnya akan meningkatkan kinerja UMKM di kota Pasuruan.

\section{KESIMPULAN}

Berdasarkan hasil pengetahuan dapat dijelskan bahwa motivasi kerja para UMKM di kota Pasuruan mampu meningkatkan kinerja UMKM didaerah tersebut. Motivasi kerja yang dimaksud adalah lingkungan kerja yang nyaman, keberadaan UMKM yang diakui, adanya kesempatan untuk mengembangkan diri, dan adanya kesempatan para pemilik UMKM dalam membimbing atau mengarahkan karyawannya agar bisa menyelesaikan tugas dengan baik maka kondisi ini akan meningkatkan kinerja UMKM yang berupa penikangkatan kreativitas pelaku UMKM, ketepatan waktu dalam menyelesaikan tugas adan adanya sinergi serta kerjasama pelaku UMKM.

Hasil penelitian juga menunjukkan bahwa kemempuan kerja pelaku UMKM mampu meningkatkan kinerja. Adanya pengetahuan dan ketrampilan dalam menjalankan usaha akan layanan akses pemasaran produk. Dengan kondisi 
meningkatkan kinerja UMKM. Para pelaku UMKM di kota pasuruan rata-rata memiliki pengetahuan dalam menjalankan usaha baik pengetahuan di bidang kroduksi, permodalan atau akses keuangan maupun pemasaran. Kondisi ini tidak terlepas dari peran pemerintah maupun swasta dalam bentuk tanggungjawab perusahaan pada masyarakat yang melakukan pendampingan dan pembimbingan bagi pelaku UMKM.

\section{KETERBATASAN}

Keterbatasan penelitian ini adalah indikator dari variabel motivasi kerja dan kinerja UMKM tidak dikembangkan berdasarkan kinerja disektor keuangan termasuk pengelolanan dan kemampuan dalam mengakses permodala. Keterbatasan penelitian ini juga pada variabel kemampuan kerja hanya terbatas pada dua indikator. Keterbatasan penelitian lainnya, penelitian ini hanya menguji pengaruh dengan menggunakan regresi linier berganda sehingga tidak diketahui bagaimana variabel observed atau indikator memilikikorelasi atau pengaruh atas variabel laten. Selain variabel penelitian, penelitian ini juga hanya meneliti sampel berdasarkan jenjeng pendidikan tertentu.

\section{SARAN}

Terbatasnya indikator untuk mengukur motivasi kerja, kemampuan kerja dan kinerja UMKM maka peneliti berikutnya perlu untuk menambahkan indikator yang sesuai. Untuk lebih memahami bagaimana variabel-variabel observed mempengaruhi variabel laten maka perlu digunakan alat analisis path atau SEM. Peneliti berikutnya juga disarankan untuk menguji kemampuan kerja berdasarkan tingkat pendidikan. Sehingga bisa membedakan apakah ada perbedaan kemampuan kerja pelaku UMKM berdasarkan tingkat pendidikan, dengan demikian perlu menambahkan sampel dengan kriteria yang berbeda.

\section{DAFTAR PUSTAKA}

Arikunto, S. 2010. Prosedur Penelitian Suatu Pendekatan Praktik. Jakarta : Rineka Cipta Askolani \& Ressi J Machdalena (2011) Pengaruh Motivasi dan Kemampuan Kerja pada Karyawan INTI (PERSERO) Bandung
Gomes, Faustino. 2003. Manajemen Sumber daya Manusia. Yogyakarta: Andi Offset

Hasibuan. SP. Malayu. 2007. Manajemen Sumber daya Manusia edisi Revisi. Jakarta: PT. Bumi Aksara

Husein Umar, 2003, Evaluasi Kinerja Perusahaan, PT. Gramedia Pustaka Utama, Jakarta

Kiki Rindi Arini, Muhammad Djudi Mukzam, Ika Ruhana (2015) Pengaruh Kemampuan Kerja dan Motivasi Kerja Terhadap Kinerja Karyawan (Studi pada Karyawan Perkebunan Nusantara $X$ ) Jurnal Administrasi Bisnis (JAB) Vol .22 No .1 $\mathrm{Me}$ i2 2015

administrasibisnis.studentjournal.ub.ac.id

Mangkunegara, AA. Anwar Prabu. 2009. Evaluasi Kinerja Sumber Daya Manusia. Bandung: PT. Refika Aditama

Marwansyah, Mukaram, 2000, Manajemen Sumber Daya Manusia, Pusat Penerbit Administrasi Niaga, Bandung

Robbins, Stephen P Timothy A. Judge. 2008. Perilaku Organisasi, Edisi 12. Jakarta: Salemba Empat

Rivai, Veithzal, 2005. Manajemen Sumber Daya Manusia. Jakarta: PT. Raja Grafindo Persada

Sakaran, Uma, 1992, Research Methods ForBussiness: A Skill Building Approach, New York, John Wiley Sons Inc. Scond Edition

Soelaiman. 2007.Manajemen Kinerja : Langkah Efektif untuk Membangun, mengendalikan dan Evaluasi Kerja : PT. Intermedia Personalia Utama

Suguino. 2010. Metode Penelitian Kuantitatif, Kualitatif, dan R\&D. Bandung: CV. Alfabeta

Tambunan, T. 2008. Daya Saing Global Indonesia 2008 - 2009 versi World Economic Forum (WEF). Jakarta : Makalah Kadin.

Tohardi Ahmad, 2002, Pemahaman Praktis Manajemen Sumber Daya Manusia, Mandar Maju, Bandung 